\title{
Research into the Influence of Implementation of the Peasants' Sports and Fitness Project on the Developmental People's Livelihood
}

\author{
Fengzhu Cao \\ Institute of Physical Education \\ Changchun Normal University \\ Changchun Jilin Province 130032, China
}

\begin{abstract}
Peasants' sports and fitness project is an important project that exerts influence on people's livelihood, and fully embodies the concept of exerting the power for the people by the Communist Party and the People's Government of China and the people-centric scientific development concept in sports efforts. The peasants' sports and fitness project in Jilin Province always takes scientific development as its theme, aims at meeting the increasing people's needs for sports, and its main task is to establish and improve the public sports service system to create a brand new situation for nationwide fitness and sports efforts, and make contributions to building a well-off society and a socialist harmonious society in an all-round way.
\end{abstract}

Keywords-Jilin Province; Peasants' Sports and Fitness Project; developmental people's livelihood; implementation

\section{PREFACE}

Jilin Province as an agricultural province, $50 \%$ of the people in the province are peasants. Peasants in the north of China often have much spare time due to its specific climate so that peasants may have sports in their spare time. It is helpful not only for improving the peasants' physique, but also for significantly improving peasants' health, as well as enriching peasants' lifestyles and promoting the formation of healthy and scientific lifestyle. Since the New China is founded, the government has been appealing to the peasants to have sports widely in the countryside under the care and guidelines of the Party Central Committee so that the peasants' sports undertaking is greatly improved and significantly develop.

Since the reformation and opening-up, as the society makes progresses in an all-round way, the rural economy of China develops fast, and their living conditions are improved in an all-round way, and the peasants' lifestyle is also changed. Due to the development of modern technology, the modern working tools bring more spare time to the peasants and the peasants' demand for fitness is also increasingly urgent. In order to ease the peasants' urgent needs for fitness, the government implements the "Peasants' Sports and Fitness Project" in due time, which emphasizes that the government will widely spread the sports facilities and instruments in the countryside based on construction of sports facilities to effectively promote the development of the mass sports in Jilin countries. In the process of building new socialist countryside, to build peasants' sports and fitness project becomes the measure that is most beneficial for the people and for China, and is a mass sports project that may improve the people's livelihood and peasants may benefit from directly.

\section{SUBJECTS AND METHODS}

\section{A. Subjects}

The subjects are the influence of implementation of peasants' sports and fitness project on the peasants' developmental livelihood

\section{B. Research methods}

Research in this paper is conducted by investigation with questionnaires. 350 peasants from 10 administrative villages from Jilin Province that have the habits of doing physical exercises are taken as subjects in this research. 350 questionnaires are distributed to them and 300 valid ones, namely, $85.7 \%$, are taken back.

\section{DEFINITION}

\section{A. Peasants' sports and fitness project}

The peasants' sports and fitness project is mainly implemented in administrative villages, and aims at building economical and practical small public sports facilities around peasants, and promoting the building of rural sports organization and sports sites to widely hold sports activities in rural areas and forming rural sports service system.

\section{B. Developmental People's Livelihood}

The Chinese word meaning the people's livelihood firstly appeared in Zuozhuan. The Twelfth Year of Emperor Xuan in the sentence "People's livelihood depends on hardworking and hardworking will bring no poverty" while in Cihai (An Encyclopedia of the Chinese Language), People's livelihood reveals the people-centric thinking and humanism. "In modern society, people's livelihood, democracy and human rights depend on each other while the basis of people's livelihood rises from the original materials for production and living to the overall pattern combing both physical needs and mental features such as living pattern, cultural pattern and citizens' spirits and so on".The developmental people's livelihood is the whole survival right and general development right of people from the angle of people's right. 


\section{IMPROVEMENT OF DEVELOPMENTAL PEOPLE'S LIVELIHOOD BY THE IMPLEMENTATION OF THE PEASANTS' SPORTS AND FITNESS PROJECT}

Since 2006, sports and fitness project has been implemented among peasants and various sports and fitness facilities are planned and then are built; the peasants' sports and fitness project is planned in an overall way and specific measures are prepared; building of other systems associated with the peasants' sports and fitness project is reinforced; distinctive rural and urban sports activities are held; sound two-level (county and village) national physique monitoring system is gradually established. The peasants' sports and fitness project is practically included in the important agenda, the rural and urban and villager committee's organization abilities shall be called into full play; peasants are inspired to go in for sports and fitness activities; great efforts are made to form the situation that the provincial, local, county, village, rural authorities assume their own roles and manage the project together while new socialist villages are built.

As at 2010, the nationwide rural sports organizations a re sound with high coverage of sports and fitness facilitie $\mathrm{s}$; a lot of peasants actively take a part in sports, and the ir awareness of the importance of having sports is reinfor ced to form a scientific, civilized and healthy lifestyle. M ore than $30 \%$ of peasants ranging from 7 to 70 years old often have sports; $30 \%$ of villages and towns in Liaonin $\mathrm{g}$ Province have built indoor and outdoor sports and fitne ss facilities; more than $15 \%$ of administrative villages hav e established public sports facilities; and each village or $\mathrm{t}$ own shall appoint one to two social sports instructors.

\section{A. Peasants' Sports and Fitness Project is a Project Geared to People'S Livelihood}

Sport originates from the need for survival of human beings and pursuit of physical and mental health, and is the product of human civilization. Socrates, an ancient philosopher, said, "Sunshine, air, water and sports are the sources of life and health." The ancient Greek Olympic Games as a pearl in the history of civilization, its spirits and ideal widely spread all over the world through modern Olympic Games. From ancient times up to now, sports is not only a physical exercise, but also embodies rich spirits and culture. Chairman Mao Zedong said: "Sports has the functions of strengthening bones and muscles, therefore improving knowledge, harmonizing emotions and strengthening wills." Sports can not only shape healthy physique, but also cultivating spirits.

Sport is ancient, and embodies our ancestors' wisdom; sport is never outdated, and represents humans' pursuit of health and happiness generation by generation. Today, sport is still one of the most positive and effective ways for us to be healthy and happy. Development of sports and encouragement of the masses to have sports is an important way for a nation to improve its people's physical health, temper its people's spirits, enrich their cultural lives, which needs less investment, brings results quickly with great comprehensive benefits. In the world today, every nation attaches great importance to the important functions of sports in improving the people's health and the advancement of the society. In China, the Communist Party and the government have been concerned and attaching great importance to the people's physical and mental health. In the historical progress of building a well-off society and a socialist harmonious society in an all-round way, healthy life and development has been widely pursued by people, and becomes an important aspect of people's livelihood. It is proposed in the Outline of 12th Five Year Program of National Economy and Social Development that "Public sports shall be vigorously developed; building of public sports facilities shall be reinforced; mass sports and fitness activities shall be widely held, and the masses', in particular youths', awareness and level of health shall be improved." Health is the basis of people's livelihood and the precondition of well-off life. To improve the masses' health level is a systemic project, needs the joint efforts in medical treatment, health, environmental protection, food safety and so on while the masses' having sports and doing exercises plays an irreplaceable role in this. The implementation of the peasants' sports and fitness project will inevitably become a new focus in guaranteeing and improving the people's livelihood.

\section{B. It is a New Measure for Improving Developmental People'S Livelihood to Build Peasants' Sports and Fitness Project and Improve the Public Sports Service System}

It is one of the main objectives of the Twelfth Five Year national economy and social development to gradually improve the basic public service system. Public sports service system is closely correlated with the people's health and livelihood, and is an important constituent of the basic public service system. In the Program, a line of new measures for establishing the public sports service system is proposed and specific requirements are also proposed in regard to building of sports sites and facilities, and holding sports activities for the masses, in this way, the establishment of the public sports service system will be inevitably greatly promoted. Holding sports activities for the masses and building the public sports service system is a social systematic project involving the joint efforts of the governments of all levels and all of departments of Jilin Province, and various social organizations to form a new development pattern of the mass sports and fitness that the government takes the lead, all the departments make a concerted efforts and all the people in China take part in the sports. All of sports workers shall be aware of their responsibilities and missions in this project and shall carefully study and widely publicize the Peasants' Sports and Fitness Project, and speed up the development of the plans for the Peasants' Sports and Fitness Project for all areas, reinforce the supervision and inspect as well as evaluation of the results of the efforts made to put all of measures in the Program in practice. For this purpose, the following tasks shall be highlighted:

Firstly, reinforcing the building of the Peasants' Sports and Fitness Project facilities. The Peasants' Sports and Fitness Project is widely implemented in the countryside and the Snow Carbon Project is implemented in economically depressed areas; and the Peasants' Sports and Fitness Project is implemented in urban and rural areas; the building of the Peasants' Sports and Fitness Project and the Peasants' Sports and Fitness Project Bases and multifunction public playgrounds for communities is supported. The building of new mass fitness facilities in residential areas is actively 
promoted. According to our visit investigation, 61\% (183) of peasants knew about the Peasants' Sports and Fitness Project, and $56 \%(168)$ of peasants were satisfied with the implementation of the project in their areas.

Secondly, the sound fitness organization network. Urban and rural sports organizations at the grass roots are developed vigorously, such sport associations as sports federations, industry sports associations, solitary sports associations and mass sports associations and so on are widely built in cities (regions), counties (districts), and sports clubs in the communities develop greatly. Normalized building of urban and rural sports fitness organizations is promoted to form a normalized, orderly and vigorous socialized mass fitness organization network is formed widely in towns and rural areas. The building of social sports instructor teams and system is reinforced, and voluntary services are provided for mass fitness. According to our visit investigations, the order of sites where peasants have sports is as follows: public sites for holding mass fitness activities in countryside (112 persons, $37.3 \%)$, the Peasants' Sports and Fitness Project (109, 36.3\%), areas where the masses gather for having sports beside farms, forests beside roads and vacant spaces (79 persons, 26.4\%); peasants are having sports in the following forms: "Doing exercises with other peasants" (230 ones, $76.7 \%)$, "Taking a part in sports activities held in the villages" (58 persons, $19.3 \%)$.

Thirdly, mass sports and fitness activities and competiti ons are widely held. The National Sports and Exercise St andard is amended and promoted and activities are widely held to try to reach the standards. A social atmosphere $r$ especting sports and fitness shall be created and the form $\mathrm{s}$ of doing exercises and specific exercises shall be innov ated; residents living in both urban and rural areas shall be attracted and inspired to keep having sports. Various $m$ ass fitness competitions at different levels are held. Accor ding to our visit investigations, 55\% (165) of peasants thi nk the Peasants' Sports and Fitness Project has enriched t heir spare time, and $41 \%$ (123 persons) of peasants consi der that the Project has changed their attitudes towards $\mathrm{sp}$ orts and fitness activities.

Fourthly, reinforcing investigation, monitoring and technical services in fitness. Building of physique monitoring and sports and fitness instruction stations shall be reinforced; and daily physique monitoring shall be conducted and scientific instructions on how to keep fit shall be given to the peasants. The national physique monitoring, sports and exercises standards as well as the systems for investigation and statistics of the situation of mass sports and the systems for issuing related information are further improved. Scientific service platforms on mass sports with the functions of disseminating knowledge and consultation are built, and scientific fitness demonstration zones are created. According to our visit investigations, $57 \%$ of peasants (171 ones) think that the Project has improved the peasants' physique and health to some extent, and $39 \%$ of them (117 ones) think the Project helps to increase the number of peasants having sports.

\section{CONCLUSIONS}

The Peasants' Sports and Fitness Project is a measure taken by Jilin Province Government to promote the building of new socialist villages, and is strategically significant for improving the peasants' physique, improving their health level, their cultural quality and the developmental livelihood of the peasants as well as promoting the development of the sports in countryside.

\section{REFERENCES}

[1] Zhang Yongjun, Xuan Lingqiang, Liu Wenjuan. Discussion of the Relationship between Sports and Health Insurance System and the Middle-Aged Persons' Life Experience in Building of New Villages [J]. Journal of Nanjing Sport Institute (Social Science Edition). 2010(04) : 49 52

[2] Zhao Jinghua, Deng Meihua, Ren Baoguo. Strategies for Promoting the Rural Economic Development by Effective Implementation of the Peasants' Sports and Fitness Project[J].Sports and Science.2010(02) : $5 \sim 7$

[3] Liu Zhimin, Ding Zhengfeng, Cheng Lihua. Current Situation of the Peasants' Sports and Fitness Project of China and the Development Strategies [J]. Sports and Science. 2009(05) : 52 55

[4] Zhang Chuanyi, Ren Baoguo. Research into the Social Value of Effective Building of Peasants' Sports and Fitness Project in New Villages[J]. Sports and Science. 2010(03) : 56 59

[5] Zhao Shengguo, Tai Chongxi, Yao Lei. Investigation and Research into the Situation of Building the Peasants' Sports and Fitness Project of Anhui Province in Building of New Villages[J].Journal of Chaohu College. 2009(06) : 105 110 